1st Medical University Clinic and Computer Center Mainz, West Germany Institute for Medical Microbiology, University of Bochum, West Germany University of Michigan and Veterans Administration Medical Center, Ann Arbor, Michigan, U.S.A.

\title{
A controlled study of supplementation with essential amino acids and $\alpha$-keto acids in the conservative management of patients with chronic renal failure
}

\author{
E. Hecking, L. Andrzejewski, W. Prellwitz, W. Opferkuch, \\ Doris Müller, and F. K. Port
}

(Received June 1, 1982)

\section{Introduction}

Restriction of dietary protein intake is widely used for conservative treatment of chronic renal failure. Severely protein-restricted diets, such as the spaghetti-egg diet (1), or the potato-egg diet (2), have been associated with indications for protein deficiency such as weight loss, acidosis, muscle atrophy, negative nitrogen balance and decrease of serum proteins (3-7). Attempts to improve these diets by addition of amino acids have not altered the reluctance of patients to follow such monotonous dietary regimens (8). To achieve a positive nitrogen balance, the Sweden-diet containing $18 \mathrm{~g}$ protein/day required oral supplementation with $16.6 \mathrm{~g}$ essential amino acids (EAA) $(9,10)$. However, this diet was difficult to apply since it required initial hospitalization and re-admission whenever dietary compliance was inadequate.

Kopple et al. (11) achieved nitrogen balance and low symptomatology with a diet of $0.6 \mathrm{~g}$ high biological value protein per $\mathrm{kg}$ body weight in patients with pre-terminal renal failure (mean GFR $=5.1 \mathrm{ml} / \mathrm{min}$ ). In contrast to the lower protein diets, the 40-g-protein diet was subjectively well tolerated and preferred by patients (12).

Beneficial effects of EAA supplementation have been reported by several groups particularly for severely protein-restricted diets. Glomerular filtration rate, blood urea nitrogen (BUN), uremic symptomatology, and nitrogen balance would improve with EAA $(10,13-16)$ or with alpha keto-analogues $(\alpha-K A)(17-19)$. However, the proposed nitrogen-sparing effect of EAA through recycling of urea has recently been challenged (20). Walser et al. (21) suggested that $\alpha$-KA induced specific metabolic effects, which were unrelated to the higher dietary protein equivalent but showed the superiority of $\alpha-\mathrm{KA}$ over EAA only in few patients. Studies by Burns et al. (22) compared EAA and $\alpha-\mathrm{KA}$ supplementation in renal failure patients on 29-49-g-protein diets and could not support any superiority of $\alpha$-KA.

Presented in part at the 2nd International Congress on Nutrition in Renal Disease, Bologna, Italy, June 1979 
Similarly, Giordano (23) could not find any advantage of $\alpha$-KA over EAA in renal failure.

For the more palatable 40-g-protein diet, Young et al. (24) have shown an improvement of the low serum-complement $\mathrm{C}_{3}$ fraction and transferrin using EAA supplementation. Some centers have even supplemented the 70-g-protein diet in hemodialysis patients with EAA or $\alpha-\mathrm{KA}$, but our own studies (25) showed no profit in this setting.

The purpose of this study was to determine if beneficial effects of EAA or $\alpha-\mathrm{KA}$ supplementation occur in patients maintained on this more palatable protein diet of $40 \mathrm{~g} /$ day rather than with the previously studied but poorly accepted dietary restriction to approximately $20 \mathrm{~g}$ protein/day. To allow practical application, the long-term effects of any dietary regimen have to be evaluated in outpatients, yet under such conditions clinically controlled studies have been scarce. We, therefore, evaluated the effect of supplementation with EAA and with $\alpha$-KA on the uremic, nutritional, and protein status and on residual renal function in ambulatory patients with advanced renal failure on a moderately restricted protein intake.

\section{Patients and methods}

32 patients with chronic renal failure entered this study. However, 17 patients had to be excluded before entering the therapeutic period, because 5 required hemodialysis and 12 refused to continue on the strict dietary protocol. Data for the remaining 15 patients who completed this study are listed in table 1.

All patients were instructed in a mixed diet according to Schmidt-DeutschKriehuber (26) containing $0.57 \mathrm{~g}$ protein $/ \mathrm{kg}$ body weight ( $40 \mathrm{~g}$ for 70 -kg-patient). Every 3 weeks, clinical, biochemical and anthropometric data were obtained and dietary instructions re-inforced. Dietary questionnaires were performed every 6 weeks.

Table 1. Patient data.

\begin{tabular}{lllllll}
\hline & & & \multicolumn{4}{l}{ S. creatinine } \\
& Age & Sex & $\begin{array}{l}\text { Weight } \\
\text { initial }\end{array}$ & $\begin{array}{l}\text { final } \\
(\mu \text { mole/liter) }\end{array}$ & Diagnosis \\
\hline DG & 22 & f & 66 & 601 & 681 & pyelonephritis \\
GH & 36 & f & 45 & 469 & 513 & pyelonephritis \\
GF & 55 & f & 52 & 566 & 672 & pyelonephritis \\
GB & 52 & f & 55 & 486 & 637 & polycystic kidneys \\
PM & 51 & m & 82 & 760 & 796 & analgesic nephropathy \\
SH & 51 & m & 97 & 601 & 663 & interstitial nephritis \\
WU & 43 & f & 56 & 460 & 460 & glomerulonephritis \\
HP & 16 & f & 45 & 628 & 681 & pyelonephritis \\
JC & 45 & m & 65 & 486 & 813 & polycystic kidneys \\
KG & 48 & m & 71 & 583 & 698 & polycystic kidneys \\
KK & 53 & m & 70 & 698 & 884 & glomerulonephritis \\
KH & 60 & m & 86 & 407 & 407 & analgesic nephropathy \\
ML & 41 & f & 51 & 460 & 530 & nephrosclerosis \\
SA & 31 & f & 56 & 530 & 451 & pyelonephritis \\
WM & 52 & m & 89 & 522 & 495 & Kimmelstiel-Wilson \\
\hline mean \pm SD & $43.7 \pm 12.6$ & $65.7 \pm 16.5$ & $551 \pm 97$ & $625 \pm 144$ & \\
\hline
\end{tabular}


Table 2. Contents of EAA-granules. Daily dose for 70-kg patient.

\begin{tabular}{ll}
\hline L-Isoleucine & $0.76 \mathrm{~g}$ \\
L-Leucine & $1.20 \mathrm{~g}$ \\
L-Methionine & $1.20 \mathrm{~g}$ \\
L-Phenylalanine & $1.20 \mathrm{~g}$ \\
L-Valine & $0.87 \mathrm{~g}$ \\
L-Histidine & $0.60 \mathrm{~g}$ \\
L-Lysine & $1.23 \mathrm{~g}$ \\
L-Threonine & $0.54 \mathrm{~g}$ \\
L-Tryptophane & $0.27 \mathrm{~g}$ \\
\hline
\end{tabular}

Total: $7.87 \mathrm{~g}$

Table 3. Contents of $\alpha$-KA-granules. Daily dose for 70-kg patient.

\begin{tabular}{ll}
\hline KA of Isoleucine & $1.22 \mathrm{~g}$ \\
KA of Leucine & $1.52 \mathrm{~g}$ \\
KA of Methionine & $0.93 \mathrm{~g}$ \\
KA of Phenylalanine & $0.85 \mathrm{~g}$ \\
KA of Valine & $1.58 \mathrm{~g}$ \\
L-Histidine & $0.27 \mathrm{~g}$ \\
L-Lysine & $0.45 \mathrm{~g}$ \\
L-Threonine & $0.34 \mathrm{~g}$ \\
L-Tryptophane & $0.17 \mathrm{~g}$ \\
\hline
\end{tabular}

Total: $7.33 \mathrm{~g}$

After a baseline period of 6 weeks on the described diet without supplementation, all patients ingested, in addition to the diet, daily $0.112 \mathrm{~g}$ of an EAA mixture/kg body weight over 6 weeks as shown in table 2 . This was followed by a 6 -week double-blind cross-over study in which 7 patients received orally $0.105 \mathrm{~g}$ of an $\alpha-\mathrm{KA}$ mixture/kg body weight, followed by 6 weeks of placebo, while 8 patients received placebo first followed by $\alpha-\mathrm{KA}$ for 6 weeks each. The $\alpha-\mathrm{KA}$ consisted of 5 ketoanalogues of essential amino acids plus the remaining 3 essential amino acids and histidine as shown in table 3 . The dose of EAA and $\alpha-\mathrm{KA}$ was adjusted in increments per $10 \mathrm{~kg}$ body weight using patient's weight to the nearest $10 \mathrm{~kg}$. The placebo contained the same vehicle but no $\alpha-K^{1}$ ). The EAA mixture supplied 1.15 of the minimum daily requirement for non-uremic patients according to Rose (27) in addition to the protein intake. The $\alpha$-KA mixture is commercially available and has similar composition (table 3 ). All patients entered the study after giving informed consent regarding purpose and risks of the investigation. Long-term medications such as antihypertensives, aluminum hydroxide, furosemide and calcium salts were maintained with occasional adjustments according to clinical indications. Throughout this study all patients received daily oral iron and multi-vitamin substitution, which had been started at least one month prior to the baseline period.

Clinical data: Patients had a physical examination every 3 weeks, at which time the level of physical and mental activity, appetite, and the presence of nausea, vomiting and edema were recorded. Measurements of body weight, triceps skinfold thickness by use of the Lange caliper (28), and upper arm circumference were obtained bilaterally and the muscle/fat ratio was derived from these data.

1) Granules containing $\alpha$-KA or placebo were kindly supplied by Pfrimmer Inc., Erlangen, W. Germany. 


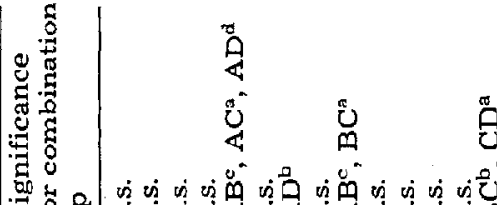

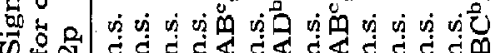

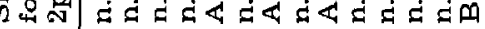

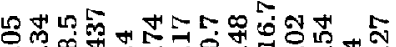
$80+1+1+1+1+1+1+1+1+1+1+1+1+1+1$

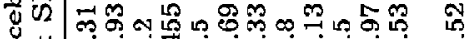

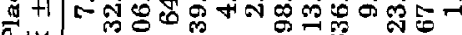
$A$ जाx

¿ 40 月

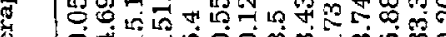
(1) 0 in P $+1+1+1+100$

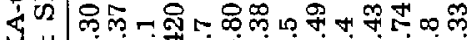

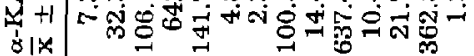

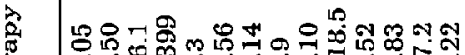
". $=0$ it $+1+1+1+1+1+1+1+1+1+1+1+1+1$

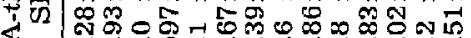
+1 m IIIXx

7

느예ำ

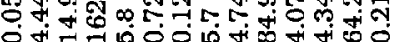
是 $+1+1+1+1+1+1+1+1+1+1+1+1+1+$

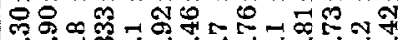

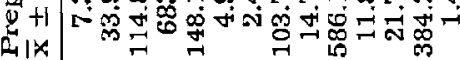
$\varangle \overrightarrow{i x}$ है

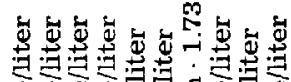
4

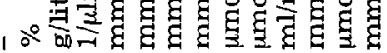

: 年

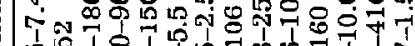

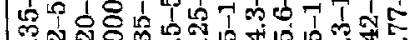

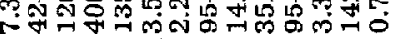

营 哭

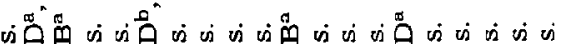
व द厶

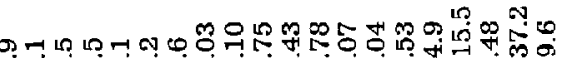

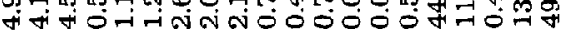
$+1+1+1+1+1+1+1+1+1+1+1+1+1+1+1+1+1+1+1+1$

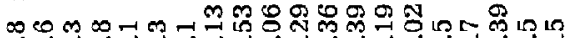

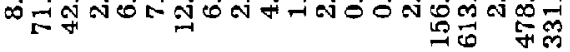

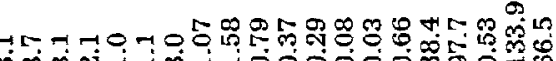

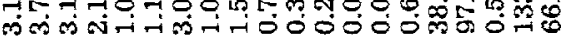
$+1+1+1+1+1+1+1+1+1+1+1+1+1+1+1+1+1+1+1+1$

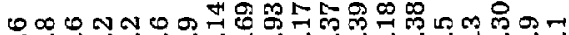

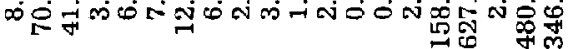

NNㅡ은

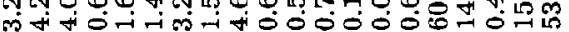
$+1+1+1+1+1+1+1+1+1+1+1+1+1+1+1+1+1+1+1+1$ ง

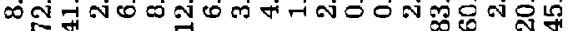
-

ง N

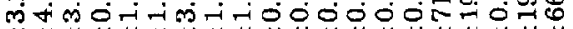
$+1+1+1+1+1+1+1+1+1+1+1+1+1+1+1+1+1+1+1+1$ nо

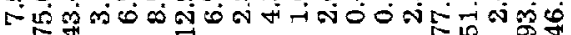

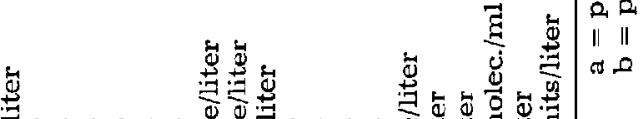

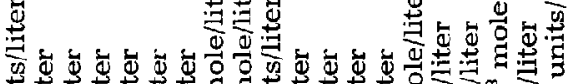

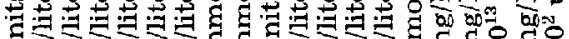
दु है

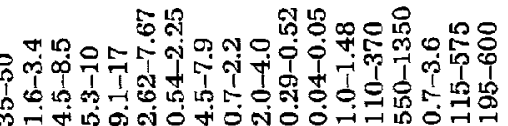

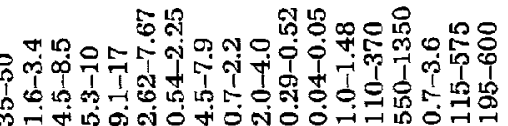

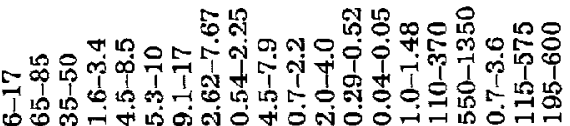

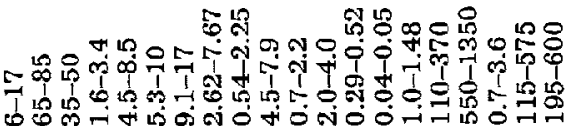

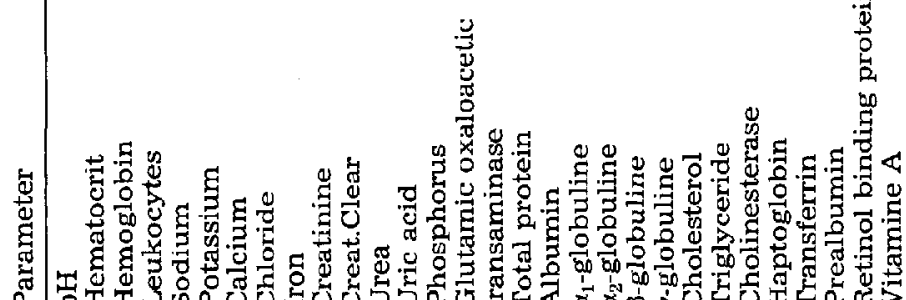

焉 
Dietary compliance: Patients and their spouses were advised every 3 weeks regarding their prescribed diet. Every 6 weeks the patients recorded, for seven days, the weighed food intake on detailed questionnaires. From these data the amount of total protein intake, the proportion of high biological value protein and the caloric intake were calculated by use of food tables.

Biochemical data: Every 3 weeks fasting venous blood samples were drawn between 7 and 9 a.m. for immediate analysis using standard techniques. The analysis of the complement components was performed after storage of the serum at $-70^{\circ} \mathrm{C}$. The biochemical parameters investigated are listed in table 4 .

Statistical analysis: The paired Student's t-test was used for comparison of means. Data collected at 3 weeks and at the end of each period as well as mean data for each period were compared. The same test was used for analysis of subgroups with higher and lower protein intakes. Clinical and biochemical parameters were also tested for significant correlation in each period by application of linear regression equations. The limits of significance were chosen for the two-sided test as $\mathrm{p}<0.05$.

\section{Results}

Physical findings: Within the different study periods, blood pressure, signs of edema, and state of health did not change, and the increasing requirements of antihypertensives, aluminum hydroxide, furosemide and
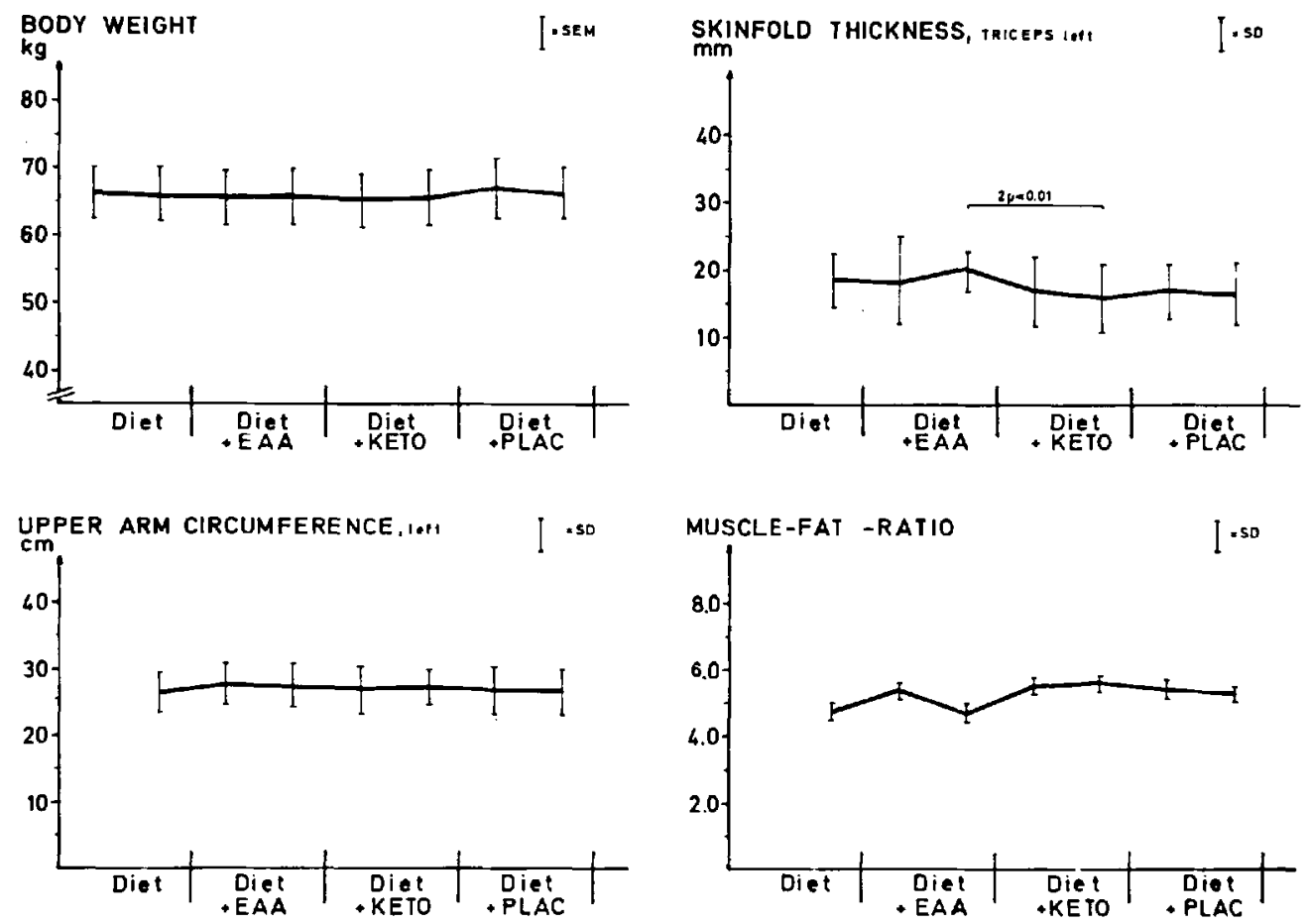

Fig. 1. Anthropometric parameters during different study periods. Supplementation with essential amino acids or $\alpha$-keto acids causes no improvement in any of these parameters. 


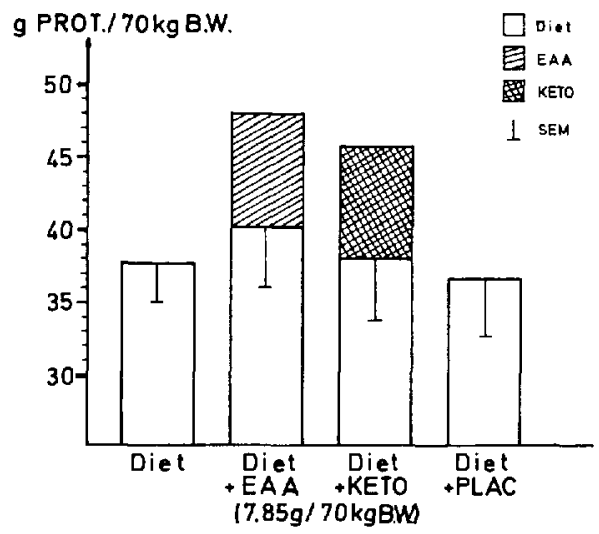

Fig. 2. Average protein intake, according to dietary questionnaires, with additional intake of essential amino acids (EAA) or $\alpha$-keto acids (KETO) for each period. The $\alpha$-keto acids are considered here as transformed to amino acids.

calcium salts were not significantly different for each period. Clinical complications of supplemental therapy could not be detected.

Anthropometric data: As shown in figure 1, body weight, upper arm circumference as well as the muscle/fat ratio did not change significantly during the different therapeutic phases. The reduction in skinfold thickness during $\alpha$-KA was significant but was the same as during placebo supplementation.

Dietary control: The daily protein intake averaged $0.528-0.571 \mathrm{~g} / \mathrm{kg}$ body weight $(37-40 \mathrm{~g} / 70 \mathrm{~kg}$ ), with animal protein accounting for $50-56 \%$. The daily caloric intake was 26.4 to $28.2 \mathrm{kcal} / \mathrm{body}$ weight (1848 to

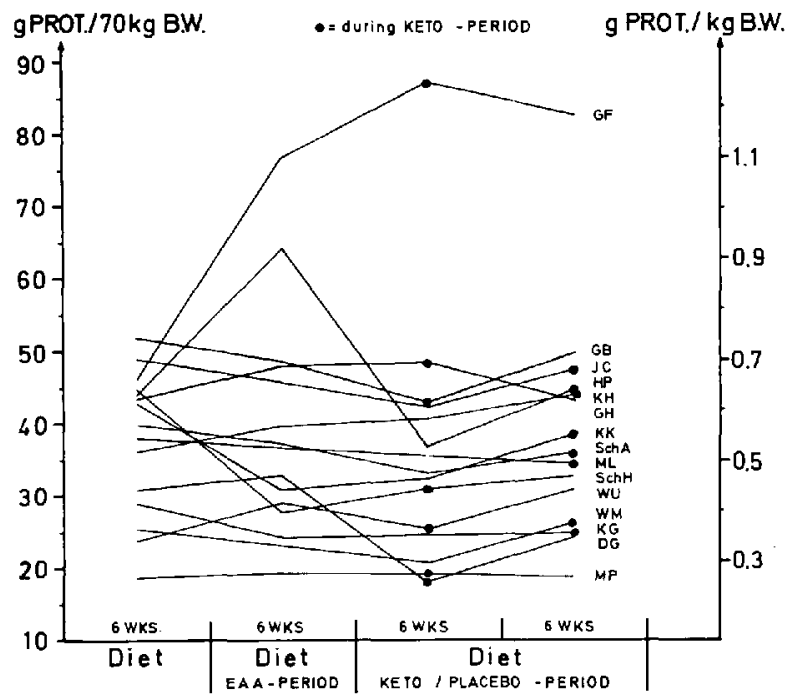

Fig. 3. Individual dietary protein intake according to 7-day recordings. The additional intake of essential amino acids or $\alpha$-keto acids is not considered. 


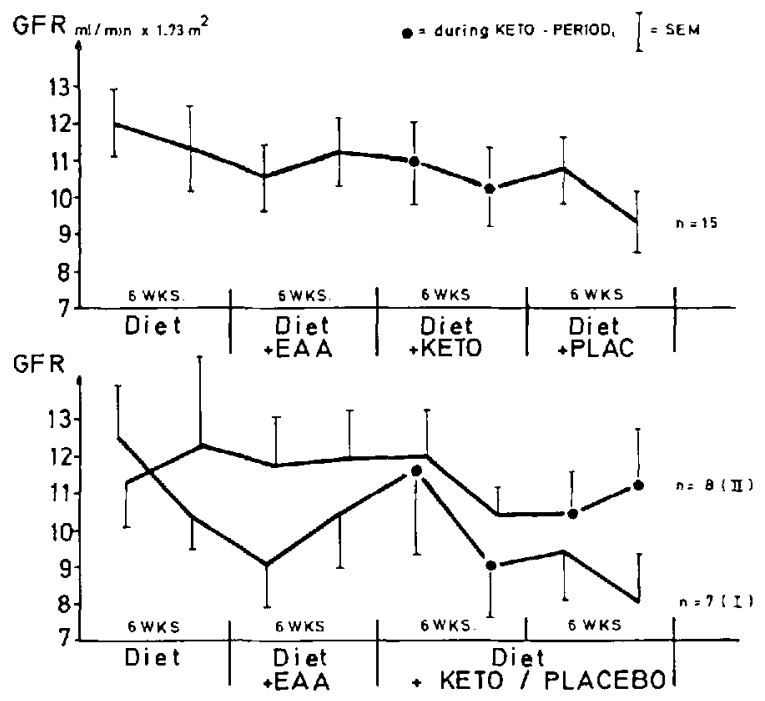

Fig. 4. The GFR as creatinine clearance is not ameliorated by therapy. The lower panel shows the two groups of patients in the $\alpha$-keto acid/placebo cross-over trial separately. The upper panel combines the data according to study periods.
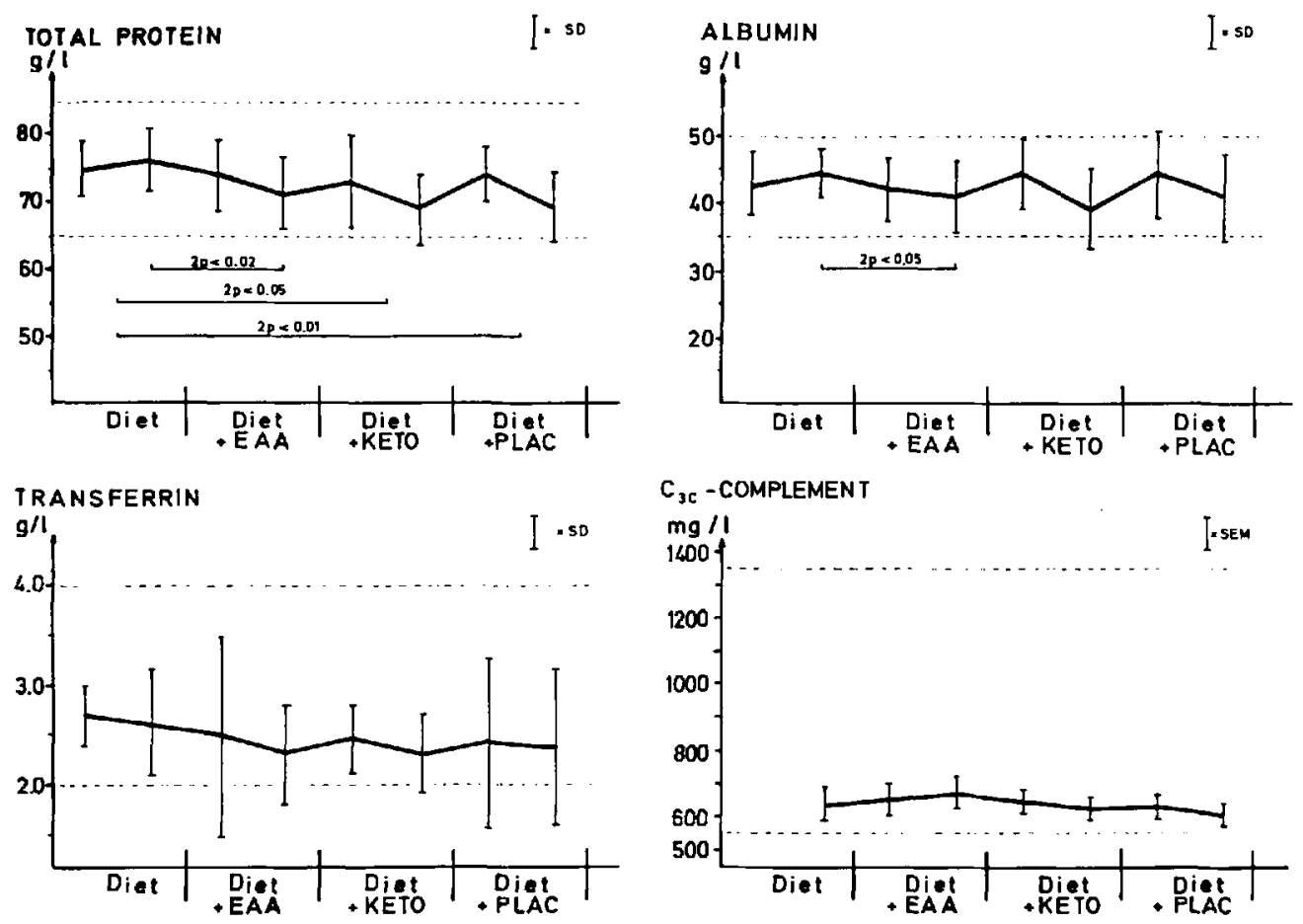

$c_{3 \mathrm{C}}$-COMPLEMEN T

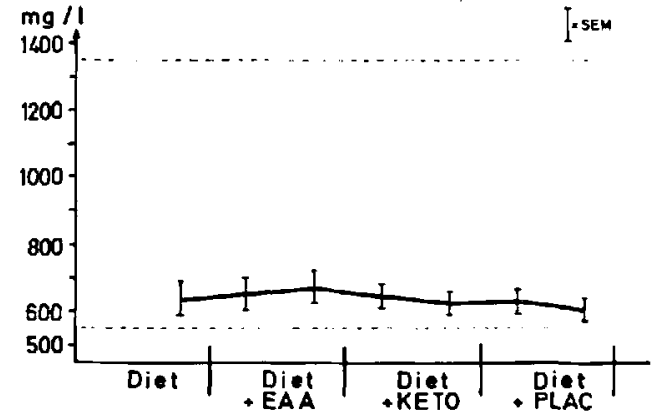

Fig. 5. Serum protein fractions during study periods. Supplementation with essential amino acids or $\alpha$-keto acids causes no improvement in any of these parameters. 
$1977 \mathrm{kcal} / 70 \mathrm{~kg}$ ). The ingestion of EAA or $\alpha-\mathrm{KA}$ was equivalent to an increase in mean dietary protein intake by almost $25 \%$, to 45.8 or $48 \mathrm{~g} /$ $70 \mathrm{~kg}$ body weight, respectively (fig. 2). The accuracy of the adherence to the medication and placebo intake was 82 and $85 \%$, respectively, as determined by counting the given and returned dosage. During supplementation, the total ingestion of high biological value proteins was therefore more than $60 \%$ of the total protein intake. Actual protein ingestion according to detailed dietary histories deviated from that prescribed and dietary counseling had little effect on dietary habits (fig. 3). Cases with the most marked deviation in dietary protein intake (such as G.F.) did not affect the overall results of this study. The protein intake correlated significantly with the urea/creatinine ratio $(p<0.001)$, independent of the therapeutic phase, however, this correlation had a wide scatter $(r=0.45)$.

Biochemical parameters: Mean values and standard deviations of laboratory data are shown for each study period in table 4. The mean creatinine clearance declined slightly but not significantly during this study ( 11.81 to $9.6 \mathrm{ml} / \mathrm{min} / 1.73 \mathrm{~m}^{2}$ ) (fig. 4) with a corresponding change in serum creatinine. Other values were abnormal as expected in renal failure, such as elevated blood urea, serum triglycerides, retinol-binding protein and vitamin $A$ and decreased hematocrit values. During different study periods, few data gave significant changes such as serum total protein and
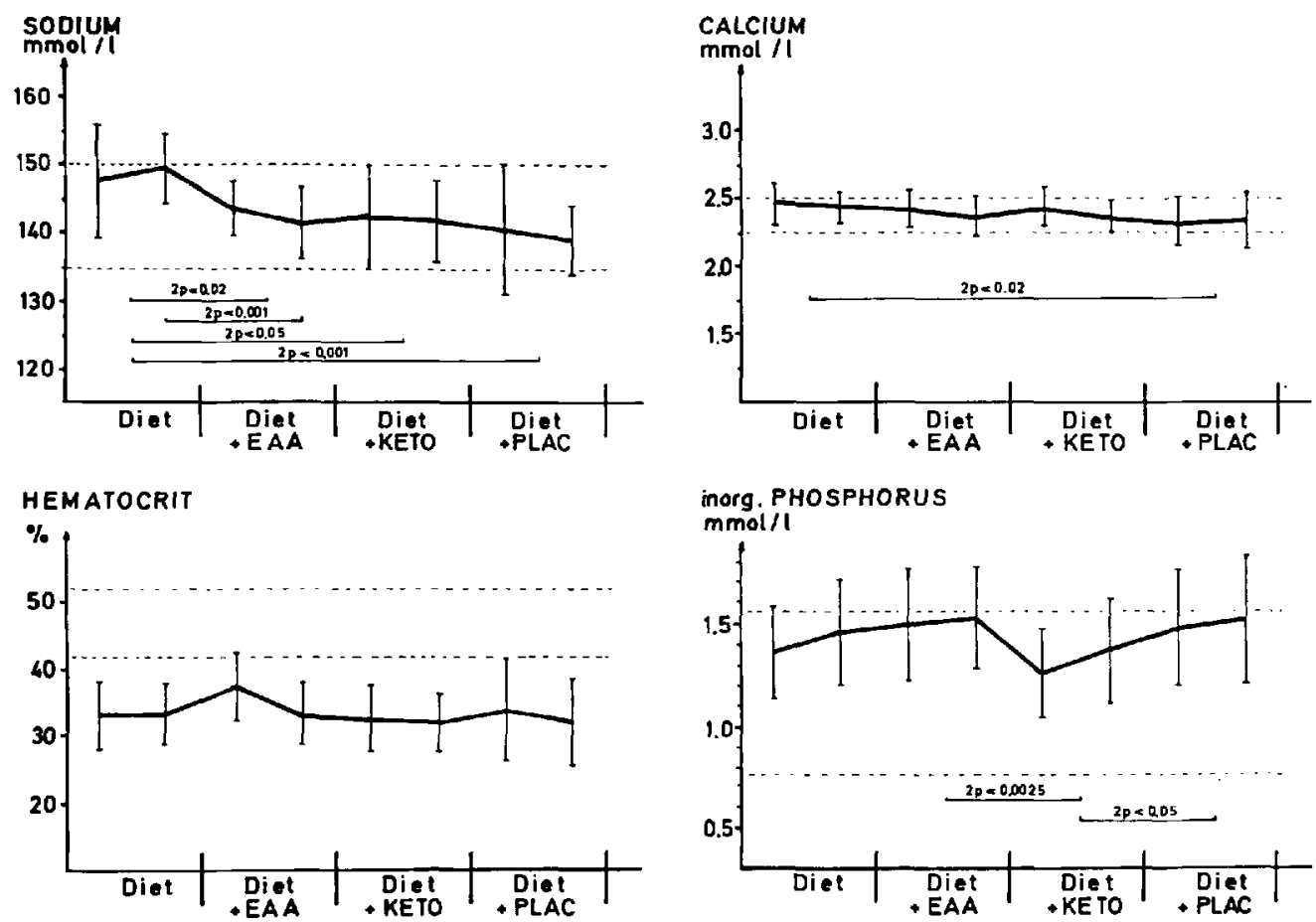

Fig. 6. Laboratory data during study periods. The decreasing concentrations of sodium and calcium with time may be explained by an increased dose of frusemide. The phosphorus levels are lowered significantly during keto-acid supplementation. 


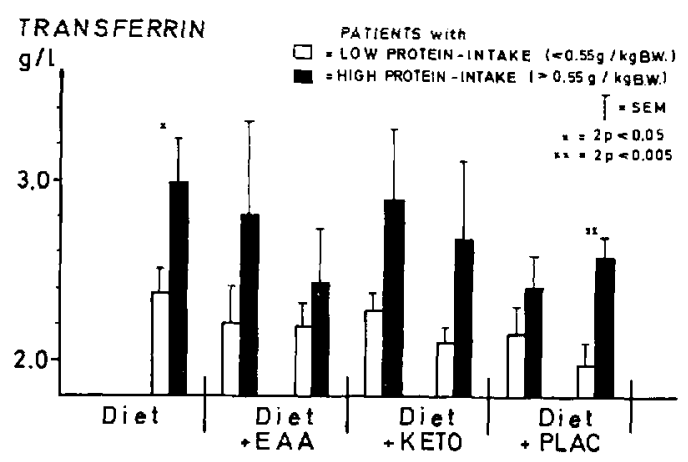

Fig. 7. Serum transferrin levels for subgroups of 8 and 7 patients with respectively lower and higher protein intake. Transferrin levels show no effects by supplementation with essential amino acids or $\alpha$-keto acids, although lower protein intake is associated with significantly lower transferrin levels.

albumin (fig. 5) and serum sodium, calcium and phosphorus concentrations (fig. 6). Analysis of data for subgroups with higher and lower protein intake for parameters of protein deficiency gave no significant changes with therapy particularly for values in the low normal range such as $C_{3 c}$ complement component and transferrin (fig. 7).

\section{Discussion}

This investigation revealed no beneficial effects regarding protein deficiency or renal function following oral supplementation with either EAA or $\alpha$-KA of a $0.57-\mathrm{g} / \mathrm{kg}$-protein diet (approx. $40 \mathrm{~g}$ ) in cooperative outpatients with renal failure. While this study was not performed on a metabolic ward, it allowed a prolonged evaluation over 6 weeks for each study period and the use of each patient as his own control. This study was limited to a very selected patient population whose renal function, though markedly impaired, deteriorated very slowly and who has remarkably cooperative regarding weighing the food, recording detailed 7-day dietary histories repeatedly and complying well to the prescribed supplementation or placebo. The degree of selection is emphasized by the early exclusion of more than $50 \%$ of patients who had signed their consent to participate.

Despite this selection and repeated dietary counseling, this study reveals and emphasizes the limitations of any outpatient investigation in that dietary protein intake deviated from that prescribed as shown by the individual lines in figure 3. On the other hand, this figure also reveals that the majority of patients maintained a relatively constant protein intake according to detailed dietary histories. Wirths et al. (29) found that dietary histories without weighing the foods would underestimate the protein intake by an average of $11 \%$ and the caloric intake by $15 \%$. This error should be less in our patients who weighed their foods. Other parameters for dietary compliance such as urinary nitrogen excretion or the urea/ creatinine ratio are dependent on many other factors and are therefore not very reliable. 
Renal function remained stable throughout the 24 -week investigation. The 5 patiens who progressed to end-stage renal failure were excluded early, 4 of them before receiving any supplementation. Therefore this study does not support the reported improvement in renal function during $\alpha-\mathrm{KA}$ supplementation $(18,19,21)$. The small but significant decreases in serum phosphorus concentration during $\alpha$-KA therapy agree with previous reports (21). The observed reduction in serum sodium and calcium concentration was probably due to a gradually increased dose of furosemide.

Our extensive laboratory investigation before and during supplementation and during placebo therapy revealed only minor indications for protein deficiency with relatively low levels of transferrin and complement $\mathrm{C}_{3 \mathrm{c}}$ component. A subgroup of 8 patients, who restricted their protein intake to less than that prescribed, had a significantly lower serum transferrin level than the 7 patients on a higher protein intake. This was independent of therapy, and renal function did not differ for the two subgroups. This indicates the sensitivity of this test and suggests that protein deficiency is more likely to occur on a protein intake of less than $0.55 \mathrm{~g} / \mathrm{kg}$ body weight. These findings thus support the observation that a severe dietary protein restriction can induce a protein deficiency.

The effect of supplementation with EAA on parameters of protein deficiency revealed a slight but statistically significant increase in the serum-haptoglobin concentration. The fact that only one out of 15 measured parameters reached statistical significance makes this significance very questionable. Furthermore, our studies on EAA supplementation in hemodialysis patients did not reveal such an increase in haptoglobin (25). The double-blind trial with a-KA supplementation indicates similarly no beneficial effect on the protein state.

The absence of clinically important benefits in biochemical parameters for EAA or $\alpha$-KA supplementation is further supported by anthropometric data which showed no improvement during any study period.

We suspect that beneficial effects of EAA or $\alpha$-KA supplementation are limited to conditions of severe dietary protein restriction as discussed or to catabolic stress in which nitrogen balance would become negative (30). Since such severe dietary restrictions are poorly accepted beyond shortterm studies, we chose to study EAA or $\alpha-\mathrm{KA}$ supplementation in patients with pre-terminal renal failure under the more practical condition of an approximately 40 -g-protein diet.

Conclusions: This study indicates that a diet of $0.55 \mathrm{~g}$ protein $/ \mathrm{kg}$ body weight is not associated with a definite protein deficiency in stable ambulatory patients with a creatinine clearance in the $10-\mathrm{ml} / \mathrm{min}$ range and that for such patients supplementation with EAA or $\alpha-\mathrm{KA}$ for 6 weeks is of no detectable benefit and would therefore appear superfluous. Since severely restricted protein diets of approximately $20 \mathrm{~g}$ protein/day have a low patient compliance, we consider that such a strict diet with costly EAA or $\alpha-K A$ supplementation is very rarely indicated.

\section{Zusammenfassung}

Art und Zusammensetzung einer optimalen eiweißarmen Ernährung für Patienten mit Niereninsuffizienz sind weiterhin umstritten. Die orale medikamentöse 
Behandlung mit essentiellen Aminosäuren oder $\alpha$-Ketosäuren wird häufig empfohlen. Unsere Untersuchungen vergleichen nacheinander bei 15 ambulanten Patienten mit chronischem Nierenversagen (mittlere Kreatinin-Clearance $10,8 \mathrm{ml} / \mathrm{min}$ ) unter einer eiweißarmen Ernährung von $0,57 \mathrm{~g} / \mathrm{kg}$ Körpergewicht $(40 \mathrm{~g} / 70 \mathrm{~kg}$ ) die Wirkung einer Substitution mit essentiellen Aminosäuren, danach die Substitution mit $\alpha$-Ketosäuren gegenüber Plazebo. Der nachgewiesene Proteingehalt in der Nahrung betrug $0,55 \mathrm{~g} / \mathrm{kg}$, die Energiezufuhr $27 \mathrm{kcal} / \mathrm{kg}$ Körpergewicht, wie mehrfach Ernährungsprotokolle über jeweils 7 Tage bei den Patienten zeigen ließen. Nach einer Vorperiode von 6 Wochen nur unter diätetischen Maßnahmen erhielten alle Patienten zusätzlich $0,112 \mathrm{~g}$ essentielle Aminosäuren/kg Körpergewicht über 6 Wochen, danach in einer Doppelblinduntersuchung $0,105 \mathrm{~g} \alpha$-Ketosäuren $/ \mathrm{kg} \mathrm{Kör-}$ pergewicht im Vergleich gegenüber Plazebo, ebenfalls jeweils über 6 Wochen. Nüchtern-Blutuntersuchungen wurden für ein Standard-Laborwertprogramm, insbesondere für 15 Proteinmangelparameter, alle 3 Wochen durchgeführt, ferner anthropometrische und klinische Kontrollen. Die Laborwerte erbrachten keine Hinweise auf einen manifesten Proteinmangel. Die Therapie mit $\alpha$-Ketosäuren erniedrigte die Phosphatspiegel signifikant $(p<0,05)$. Dagegen konnten weder unter essentiellen Aminosäuren oder $\alpha$-Ketosäuren andere für den Patienten wesentliche Effekte nachgewiesen werden. Deshalb erscheint uns eine Substitution mit essentiellen Aminosäuren oder Ketosäuren überflüssig bei Patienten mit einer chronischen Niereninsuffizienz, die sich in einem stabilen Stoffwechselgleichgewicht befinden und mit einer Eiweißzufuhr von 0,55 g/kg Körpergewicht behandeit werden.

\section{Abstract}

Oral therapy with essential amino acids (EAA) or $\alpha$-keto acids ( $\alpha$-KA) has been recommended in patients with renal failure, but quality and quantity of optimal protein intake are still controversial. This study compares sequentially the effect of supplementation with EAA, and with $\alpha-\mathrm{KA}$ versus placebo in 15 ambulatory patients with chronic renal failure (average creatinine clearance $10.8 \mathrm{ml} / \mathrm{min}$ ), maintained on a protein diet of $0.57 \mathrm{~g} / \mathrm{kg}$ body weight ( $40 \mathrm{~g}$ for a $70-\mathrm{kg}$ patient). The actual dietary intake averaged $0.55 \mathrm{~g}$ protein $/ \mathrm{kg}$ and $27 \mathrm{kcal} / \mathrm{kg}$ according to repeated 7 day dietary recordings. After a 6-week baseline period on this diet, all patients received additionally $0.112 \mathrm{~g} \mathrm{EAA} / \mathrm{kg}$ for 6 weeks followed by a double-blind crossover study of $0.105 \mathrm{~g} \alpha-\mathrm{KA} / \mathrm{kg}$ versus placebo supplementation for 6 weeks each. Fasting blood samples for multiple parameters, including 15 indicators for protein deficiency, as well as anthropometric and clinical data were evaluated every 3 weeks. Laboratory data revealed no indications of protein deficiency. Therapy with $\alpha$-KA diminished serum phosphate concentration $(p<0.05)$, however no other significant beneficial effects could be demonstrated during supplementation with either EAA or $\alpha-\mathrm{KA}$. Therefore, such supplementation to a $0.55-\mathrm{g} / \mathrm{kg}$-protein diet appears superfluous in stable ambulatory patients with renal insufficiency.

Key words: chronic renal failure, dietary treatment, essential amino acids, $\alpha$-keto acids, nutrition

\section{References}

1. Giovannetti, S., Q. Maggiore: A low-nitrogen diet with proteins of high biological value for severe chronic uraemia. Lancet 1964/I, 1000-1003.

2. Kluthe, R., H. Quirin: Diätbuch für Nierenkranke (Thieme, Stuttgart 1967).

3. Coles, G. A.: Body composition in chronic renal failure. Quart. J. Med. 41, 25 (1972).

4. Fürst, P., J. Bergström, M. Ahlberg, L.-O. Noree, E. Vinnars: Stoffwechsel und Therapie bei akuten und chronischen Nierenerkrankungen. Nieren- und Hochdruckkrankheiten 3, 234 (1974). 
5. Kult, J., G.-P. Dragoun: Low molecular serum proteins in uremic patients. In: Heidland, A., H. Hennemann, J. Kult (eds.): Renal Insufficiency, 115-120. Würzburg Symposium 1974 (Thieme, Stuttgart 1976).

6. Schmicker, R.: Diät bei chronischer Niereninsuffizienz. Z. Urol. Nephrol. 69, 763-767 (1976).

7. Lüttgen, F.-M.: Rehabilitation und Diät bei chronischer Niereninsuffizienz. Akt. Ernähr. 2, 26-28 (1977).

8. Llach, F., S. S. Franklin, M. H. Maxwell: Dietary management of patients in chronic renal failure. Nephron 14, 401-412 (1975).

9. Bergström, J., P. Fürst, L.-O. Noree: Treatment of chronic uremic patients with protein-poor diet and oral supply of essential amino acids. I. Nitrogen balance studies. Clin. Nephrol. 3, 187-194 (1975).

10. Noree, L.-O., J. Bergström: Treatment of chronic uremic patients with proteinpoor diet and oral supply of essential amino acids. II. Clinical results of longterm treatment. Clin. Nephrol. 3, 195-203 (1975).

11. Kopple, J. D., J. W. Coburn, M. E. Rubini: Nitrogen requirement in chronic uremia, p. 271-281. In: Kluthe, R., J. G. Berlyne, B. Burton: Uremia (Thieme, Stuttgart 1972).

12. Kopple, J. D.: Treatment with low protein and amino acid diets in chronic renal failure, 497-507. In: Barcelo, R., M. Bergeron (eds.): Proc. VIIth Int. congr. Nephrol., Montreal, June 1978 (S. Karger, München-Basel-Paris 1978).

13. Giordano, C.: Diet and amino acids in uremia. Proc. Eur. Dial. Transpl. Assoc. 9, 419-436 (1972).

14. Kopple, J. D., M. E. Swendseid: Amino acid and keto acid diets for therapy in renal failure. Nephron 18, 1-12 (1972).

15. Rippich, Th., N. Katz, G. Schaeffer, M. Schanz, S. Schinle, A. Südhoff, W. Zimmermann, R. Kluthe: Detoxification and amino acid metabolism in chronic uremia: A therapeutic approach using biochemically defined liquid diets, 174-180. In: Heidland, A., H. Hennemann, J. Kult: Renal Insufficiency, Würzburg Symposium 1974 (Thieme, Stuttgart 1976).

16. Young, G. A., H. I. Oli, A. M. Davison, F. M. Parsons: The effects of calorie and essential amino acid supplementation on plasma proteins in patients with chronic renal failure. Amer. J. Clin. Nutr. 31, 1802-1807 (1978).

17. Walser, M., A. W. Coulter, S. Dighe, F. R. Crantz: The effect of keto-analogues of essential amino acids in severe chronic uremia. J. Clin. Invest. 52, 678-690 (1973).

18. Walser, M.: Ketoacids in the treatment of uremia. Clin. Nephrol. 3, 180-186 (1975).

19. Barsotti, G., A. Guiducci, F. Ciardella, S. Giovannetti: Effects on renal function of a low-nitrogen diet supplement with essential amino acids and ketoanalogues and of hemodialysis and free protein supply in patients with chronic renal failure. Nephron 27, 113-117 (1981).

20. Richards, P.: Nitrogen-recycling in uremia: A reappraisal. Clin. Nephrol. 3, 166-167 (1975).

21. Walser, M.: Keto-analogues of essential amino acids in the treatment of chronic renal failure. Kidney Intern. 13 (Suppl. 8), 180-184 (1978).

22. Burns, J., E. Cresswell, E. Ell, M. Fynn, M. A. Jackson, A. Lee, P. Richards, A. Rowlands, T. Talbot: Comparison of the effects of keto acid analogues and essential amino acids on nitrogen homeostasis in uremic patients on moderately protein-restricted diets. Amer. J. Clin. Nutr. 31, 1767-1775 (1978).

23. Giordano, C.: Amino acids and ketoacids - advantages and pitfalls. Amer. J. Clin. Nutr. 33, 1649-1653 (1980).

24. Young, G. A., J. B. Keogh, F. M. Parsons: Plasma amino acids and protein levels in chronic renal failure and changes caused by oral supplements of essential amino acid. Clin. Chim. Acta 61, 205-213 (1975).

25. Hecking, E., H. Köhler, R. Zobel, E.-M. Lemmel, H. Mader, W. Opferkuch, W. Prellwitz, H. J. Keim, D. Müller: Treatment with essential amino acids in 
patients on chronic hemodialysis: A double-blind cross-over study. Amer. J. Clin. Nutr. 31, 1821-1826 (1978).

26. Schmidt, P., E. Deutsch, J. Kriehuber: Diät für chronisch Nierenkranke (Springer, Berlin-Heidelberg-New York 1973).

27. Rose, W. C.: Amino acid requirements of man. Fed. Proc. Amer. Soc. Exp. Biol. 8, 546 (1949).

28. Lange, K. O., J. Brozek: A new model of skinfold caliper. Amer. J. Phys. Anthropol. 19, 98-105 (1961).

29. Wirths, W.: Ermittlung des Ernährungszustandes. In: v. Cremer, H.-D., L. Heilmeyer, H.-J. Holtmeier, D. Hötzel, H. A. Kühn, J. Kühnau, N. G. Zöllner: Ernährungslehre und Diätetik., 50-89, Vol. III (Thieme, Stuttgart 1974).

30. Grodstein, G. P., M. J. Blumenkrantz, J. D. Kopple: Nutritional and metabolic response to catabolic stress in uremia. Amer. J. Clin. Nutr. 33, 1411-1416 (1980).

\section{Authors' address:}

Prof. Dr. E. Hecking, Nephrologische Abteilung, Augusta-Kranken-Anstalt, Bergstraße 26, 4630 Bochum 1 